\section{Taming the last lawless frontier}

Washington

Although it will be several years before astronauts are working together in a multinational space station, it is not too soon for Congress to start considering legal questions that might arise, according to the Office of Technology Assessment (OTA).

Some US laws, Congress's research office notes in a recent background paper*, do not make much sense in space. The US Uniform Commercial Code, for example, with its definitions of personal property and real estate, and what is movable and what immovable, could not be applied "without serious uncertainty". The wisdom of applying the Buy-America Act is similarly unclear. And OTA notes it might be "inappropriate" to apply the Fair Labour Standards Act, with its stipulated 8-hour maximum working day.

More seriously, the application of intellectual property, product liability and export laws in a space station is likely to be important for commercial companies working on the space station. Although the 1967 Outer Space Treaty established some basic principles governing countries' responsibilities and liabilities in space, it leaves many questions unanswered. OTA recommends that Congress start thinking

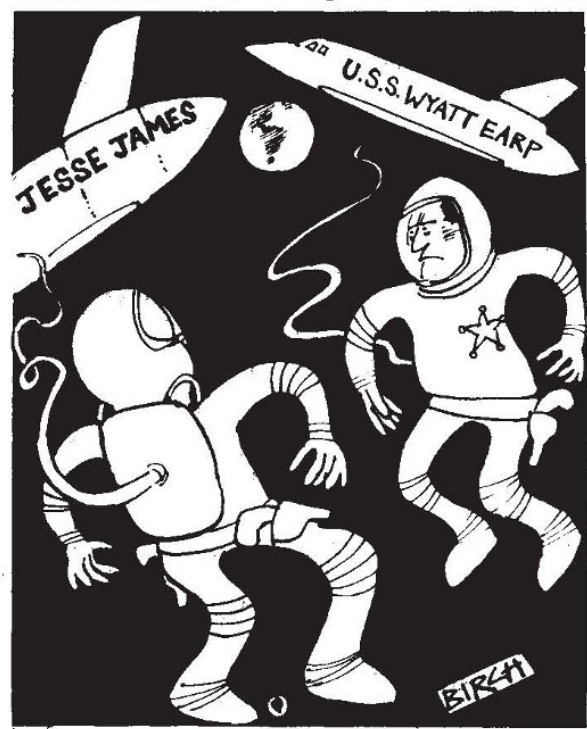

immediately about how far US federal and state law can be applied in space, and how disputes might be resolved.

How to determine the jurisdiction of different countries over different parts of a multinational space station is seen by OTA as central. Both Europe and Japan are expected to contribute habitable modules; although the simplest thing from the US point of view would be to have everything under US law, this "may be politically unacceptable to other space station partners". OTA notes.

Patent law is likely to be especially diffi- cult to sort out in space. There is already a variety of opinions on how far US patent law can be applied, and attempts in Congress to clarify the situation have not been very successful. Real disputes are likely to arise, since there are important differences in patent laws between nations.

In the case of criminal law, the question on enforceability also arises. So far crews have been highly disciplined and engaged in specific tasks. But as more people start to live and work in space there may be disputes. On space shuttle missions, the

\section{UK universities}

THE British government now seems willing to provide the extra money needed to prevent university closures - provided, that is, universities agree to reform and to their performance being monitored.

The news represents a victory for those who believe the only way to persuade the government to invest more heavily in the universities is by showing a quiet willingness to make improvements (or by being submissive, as cynics have it). Beginning in 1981, financial cuts have brought several universities to their knees: at least four are thought likely to have to close during 1987 if help is not forthcoming. The political embarrassment that this could generate in an election year, plus the new willingness of the universities to accept reform and monitoring seems, according to reports from the Department of Education and Science, to have persuaded the Secretary of State. Mr Kenneth Baker. to take out his chequebook, if not actually to sign the cheque.

Some of the changes the universities may have to accept are contained in the report on "Academic Standards in Universities" just released from the Committee of Vice Chancellors and Principals. Perhaps its most radical suggestion, for British academics at least, is that students should help appraise courses and lecturers. A host of other course evaluation measures are suggested: the number of applicants, the qualifications of entrants. degree results. percentage of drop-outs and so on. The report also seeks to lay down codes of conduct for external examiners. who will ensure that degrees awarded in similar subjects are comparable in standard in different universities: for postgraduate training and research: and for an appeals procedure for postgraduates who fail to be awarded degrees. The latter codes are intended to help deal with the embarrassingly high drop-out and failure rates among post-graduate students. The responsibilities of a doctoral supervisor commander has broad authority to enforce discipline. But if a British astronaut were to assault an American astronaut in the British portion of a space station, US laws could not be enforced without a prior agreement.

One way of avoiding complicated legal entanglements, according to OTA, would be for participating countries to enter in to "pre-launch agreements" modelled on the "status of force agreements" between members of the North Atlantic Treaty Organization which clarify legal questions about forces stationed in different countries.

Tim Beardsley

Sace Stations and the Law: Selected Legal Issues. Office of Technology Assessment Background Paper. 1986.

\title{
Government yields just a little
}

are made explicit for the first time and it is recommended that a statement to establish clear mutual expectations between student and supervisor always be drawn up.

The other issues on which the government wants to see progress are financial management, the creation of performance indicators so that whole universities might be appraised, and the rationalization of university departments that are judged too small or too weak. University performance indicators were set out in the Jarrat report last year: they include. among other things, the success of graduates in obtaining employment: publications by staff and citations: patents. inventions, and consultancies: prizes: and papers given at conferences (see Nature 314. 393: 1986).

The University Grants Committee has already set in motion an assessment of individual departments research quality which seems set to lead to the closure of those judged inefficient. This has proved controversial: not only because of the uncertainties involved in assessment (see Nature 322, 219; 1986), but because small departments are emerging as the prime candidates for closure. While manv will acknowledge this makes sense in areas where a critical mass of researchers is required to maintain expensive laboratory facilities. it mav be a different story when it comes to subjects like the history and philosophy of science. There is a strong argument that the present situation. with sixty or so staff scattered over 25 universities, is the best way to allow many scientists to absorb some history and philosophy of science: to say that it should be concentrated in a few places is to denv its general relevance. Similar arguments over the rationalization of departments of philosophy are now provoking public debate and it is too soon to say whether philosophy will be seen as just a discipline for specialists.

Alun Anderson 